\title{
Commentary: The potential for multi-span continuous timber-concrete composite floors
}

1 Wendel Sebastian MA (Cantab), PhD (Cantab) Reader, University College London, London, UK

2 Andrew Lawrence MA (Cantab), PGCDMM, CEng, MIStructE, MICE

Associate Director, Arup Advanced Technology + Research, London, UK
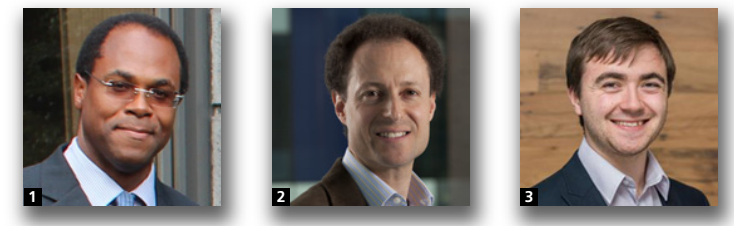

3 Andy Smith BA, MEng (Cantab) Structural Engineer, Arup Advanced Technology + Research, London, UK
As the only renewable construction material, and owing to the superior specific stiffnesses and strengths of the different species, timber has been used in major load bearing applications for thousands of years. The advent of waterproof adhesives during World War II and recent advances in manufacturing have combined to exploit the ease of forming and machining this material, leading to various forms of engineered timber including glulam, laminated veneer lumber (LVL) and cross-laminated timber (CLT). Manufactured in lightweight modules that are easily transported, then quickly craned into position and connected to produce eye-catching structures, engineered timber provides cost-effective alternatives (with minimal numbers and complexity of connections) to conventional materials for rapid construction of affordable residential and office spaces in busy city centres.

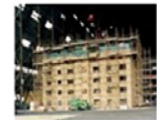

2000

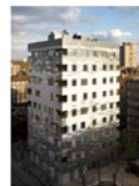

2008

Techniker
(C) Waugh Thistleton

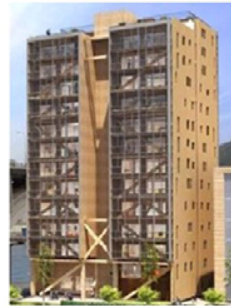

2012

Sweico

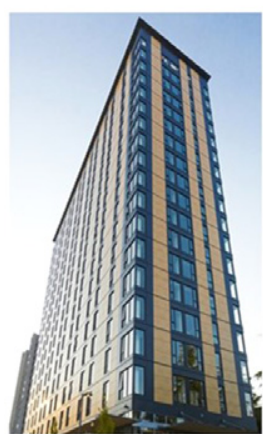

2017

Fast \& Epp

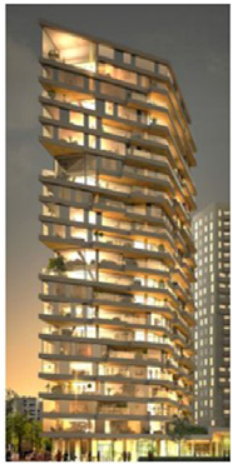

2019

Arup
(C) naturallywood.com/Brudder (C) Team V Architecture 


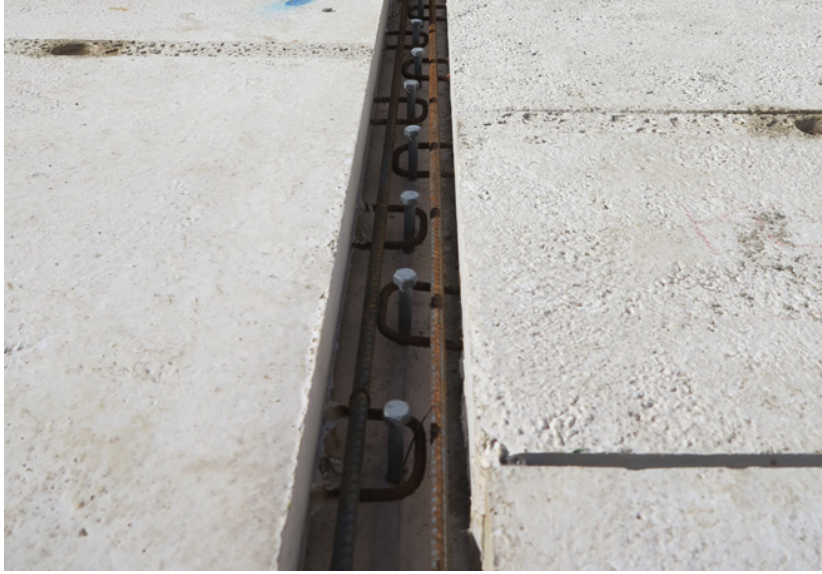

(a)

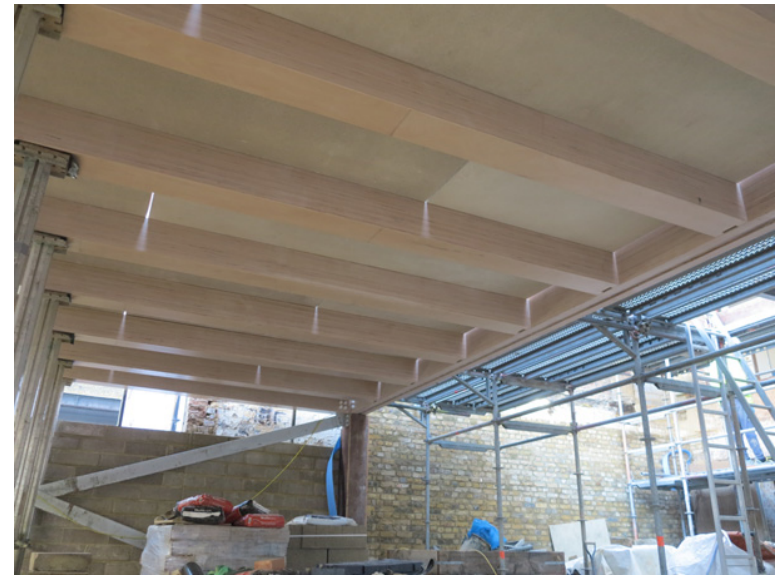

(b)

Figure 2. Precast TCC floor, Anna Freud Centre, London, UK (2018, courtesy Webb Yates): (a) connectors as seen from above before casting concrete stitch; (b) view from below, showing hardwood LVL joists under slab

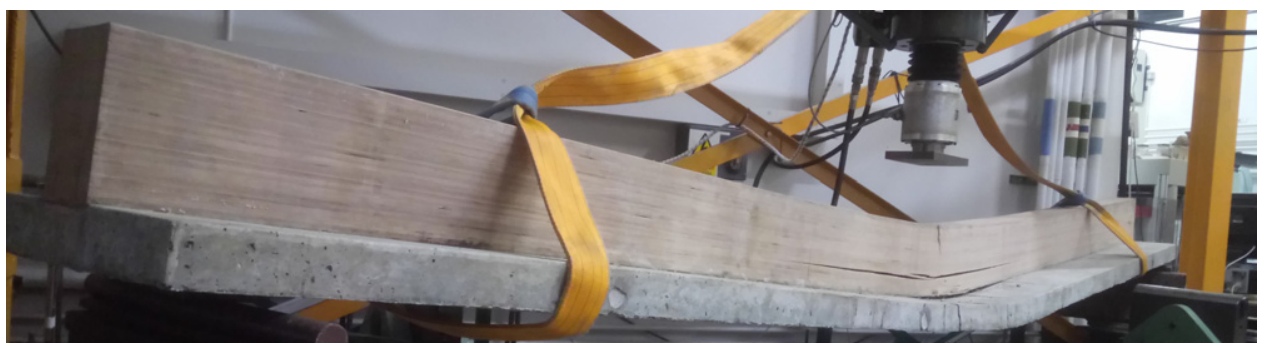

Figure 3. Residual profile of TCC T-beam tested at University College London, UK

leading to cheaper foundations or to the possibility of construction on poor soils, and they exhibit superior stiffness (thus better vibration characteristics), strength, thermal mass and fire resistance over all-timber floors.

To date, the application of TCC floors has largely been confined to a few prestigious structures worldwide, including the oval classroom floors of the Dr Chau Chak Wing building (University of Technology Sydney, Australia) designed by visionary architect Frank Gehry, and the free floating staircase in the atrium of the University of British Columbia's Earth Sciences building in Vancouver. A current TCC example, now under construction within the Anna Freud Centre in London, comprises precast concrete slabs shear connected to hardwood LVL joists via M12 coach screws drilled into the joists, reinforcing steel U-bars projecting from the precast units and cast in-situ concrete stitching. Figure 2 shows the arrangement.

Eurocode 5 (BSI, 2014), the Eurocode for design of timber structures, is currently being updated including a new section dedicated to TCCs. This underlines the importance of TCC technology and will encourage its wider use in practice.

A key issue is that, to date, the TCC floors which have been researched and applied in practice are almost exclusively simply supported single spans. Multi-span continuity can be used to enhance the stiffness, strength, robustness and ductility of TCC floors, but the relevant underpinning research has so far received little attention. This situation has prompted some just-completed pilot work by the first author at University College London to gain initial insight into the nonlinear mechanics in crucial zones of continuous TCC floors. Figure 3 shows the residual deflected shape of one TCC T-section test specimen. The recorded data show that continuity can indeed introduce crucially important structural benefits. Further work in this area will usher in a new era of highly cost-competitive and robust floor construction.

\section{REFERENCE}

BSI (2014) BS EN 1995-1-1:2004+A2:2014: Eurocode 5: Design of timber structures - part 1-1: general - common rules and rules for buildings. BSI, London, UK. 